\title{
'WATER WATER EVERYWHERE': Attempts at drought-proofing properties using surface water infrastructure in central western Queensland in the early 1880s
}

\author{
Luke Godwin and Scott L'Oste-Brown
}

\begin{abstract}
There is a long and continuing history in Australia of private enterprise and governments attempting to 'drought-proof' businesses and communities. In this paper we explore the strategies employed for this purpose in the late nineteenth century on the massive Wellshot Station, jewel in the crown of the Australian wool industry, in central western Queensland. We describe some of the technology used and its archaeological footprint. Questions reviewed include the purpose and operation of the water management facility, as well as when it was built and who constructed it. We consider the overall efficacy of this, and subsequent technologies, in sustaining the huge sheep flocks depastured on this property. We demonstrate that the highest rates of stocking on the property were achieved during the period when surface water, rather than groundwater, was harvested. We then turn our attention to the broader implications of this success, noting that the use of this technology on Wellshot, and throughout the region, resulted in massive profits being made by the pastoralists during the last few decades of the nineteenth century. These pastoralists deployed these financial resources for larger economic and industrial purposes, which in turn triggered unexpected responses that have had political ramifications through to the present day.
\end{abstract}

\section{Introduction}

The management of water, and more particularly securing adequate supplies of this resource in the world's driest inhabited continent, remains a constant issue for Australian governments, the public and industry. The increasing sense that this is a finite and precious resource has seen major programs to cap groundwater bores in the Great Artesian Basin (GAB) - once seen as an apparently inexhaustible resource - in Queensland (QLD), New South Wales (NSW), South Australia (SA) and the Northern Territory (NT). Additionally, wholesale reviews of water entitlements and allocations in the context of water management planning have been the subject of much recent discussion at both State and Federal levels. As part of this, water licence buy-back programs (aimed at limiting the use of water from river systems to irrigate water-intensive crops associated with significant degradation of the environment through diminished natural flows) are a hotly debated issue.

This raises an interesting paradox. There is now an unparalleled capacity to measure the availability of water, plan for its use and construct huge systems to capture, store and then redistribute it. Interestingly, however, the greatest sheep stations in Australian history, whose flocks in their heyday numbered at

Central Queensland Cultural Heritage Management, 16 Moren St, North Rockhampton QLD 4701, Australia AND

Department of Anthropology, Archaeology and Sociology, School of Arts and Social Sciences, James Cook University, Cairns QLD 4870, Australia Imgodwin@bigpond.com indiana@irock.com.au times into the hundreds of thousands, were established in the nineteenth century - well before any of this technology was available - in areas to the west of the Great Dividing Range in the arid zone. Moreover, even after various improved technologies and management strategies (notably the ability to draw on groundwater from the GAB) became available, these stations fell away, never to achieve their earlier carrying capacity. While it is true that Australia no longer 'rides on the sheep's back', even before the major contraction of the industry associated with the demise of the Australian Wool Corporation and the wool reserve price scheme in the early 1990s, stocking rates have never again reached those achieved during the 1880s and 1890s.

In this paper we explore this issue by focusing on the sheep industry of central western QLD, and on one property in particular: Wellshot Station. Lying between Barcaldine and Longreach, some $600 \mathrm{~km}$ to the west of Rockhampton, Wellshot can stake a claim to having been one of the truly great sheep stations in Australian history ${ }^{1}$. In 1891 more sheep raised on Wellshot's own pastures were shorn in one season than anywhere else in Australia, either at that time or since. Indeed, measured in these terms, it is perhaps the largest sheep station that has ever existed anywhere in the world.

It is interesting that, despite the reliance Australia placed on sheep husbandry and especially the production of wool, the technology associated with its earliest phases has attracted relatively little interest in the historical archaeological literature. Pearson (1984) described facilities associated with the washing and scouring of wool in northwestern NSW. This was initially seen as an essential aspect of the industry when the challenge of reducing the costs of transporting this commodity long distances for export was critical for the establishment of a viable industry. The mechanical wool scour in Blackall (home of Jacky Howe², the greatest shearer of them all, also in central western QLD) has attracted considerable research interest, as well as funding for its conservation.

Connah (1977, 1988:95-101) described several wool-related historic sites in the New England Tablelands of NSW and elsewhere, and briefly summarised some other data regarding aspects of the industry. Among other things, he described the

\footnotetext{
This paper had its genesis in two separate pieces of work, neither focusing on the history of the wool industry. The first was a study of the archaeological footprint of South Sea Islander people in central QLD, undertaken while we were employed in the Department of Environment and Heritage prior to 1997. The second was a cultural heritage assessment of the proposed realignment of the llfracombeIsisford Road planned by the Department of Main Roads. It was during the latter work that we undertook the detailed recording of the Wellshot Shotover and associated features reported herein. It was combining the results of these two separate programs that sparked our interest and prompted us to explore the issues examined in this paper.

2 The record generally accepted for blade shearing is held by Jackie Howe. In 1892 he shore 321 sheep in 7 hours 40 minutes at Alice Downs, near Blackall. Shearing machines were first used in Australia in NSW in 1887. Today, a shearer normally shears around 160 to 170 sheep a day.
} 


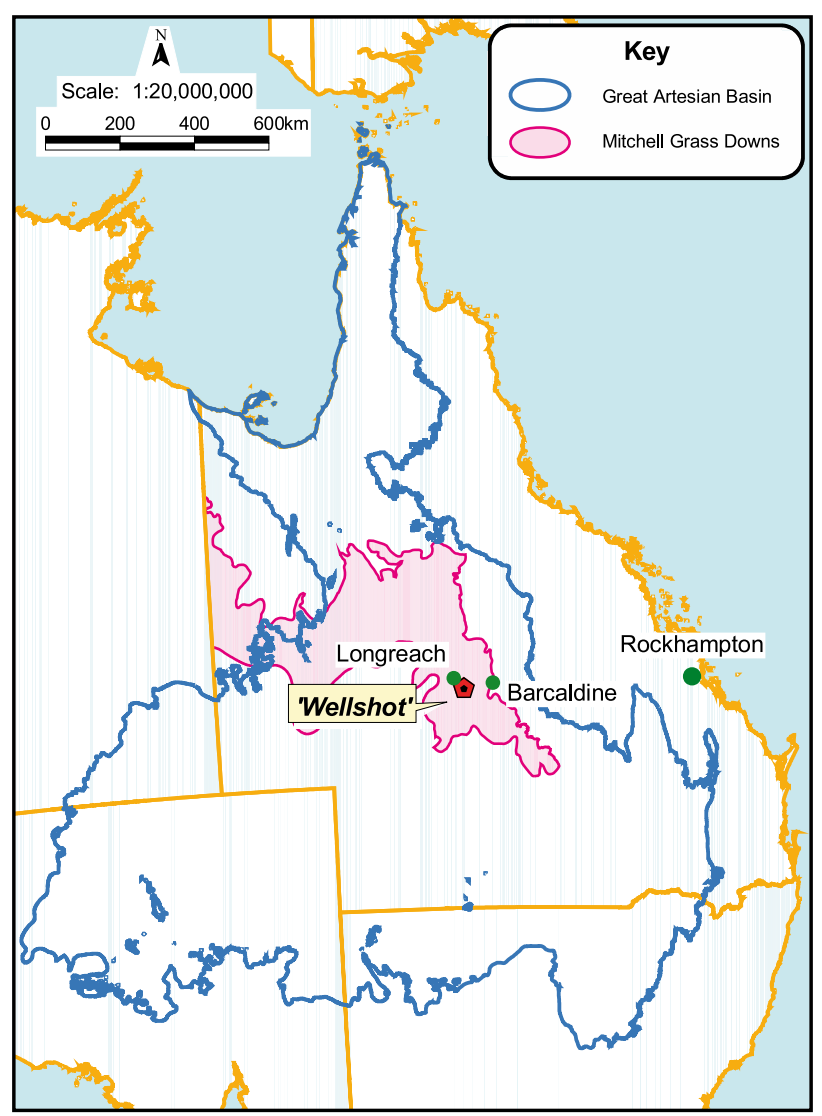

Figure 1 Location of Wellshot Station in relation to the Great Artesian Basin and the Mitchell Grass Downs biogeographic zone within central western Queensland.

great shearing shed at Gostwyck dating from the early 1850s, where hundreds of men laboured to remove and bale the fine wools of the region, as well as aspects of the early sheep industry on Saumarez Station. He also investigated water management technology in the same region, though this, while impressively involving the construction of a small race running several kilometres from a natural lagoon, was to provide power to drive a flour mill. Godwin (1986) documented races extending for up to $10 \mathrm{~km}$ in the same region, but these were associated with gold mining using the sluicing technique. Others have examined aspects of the wool industry focusing on industrial-scale wool scours and the distribution of shearing sheds in southwestern NSW and Victoria (Cannon 1992; Cummins 1989).

The development of the bore systems that drew on the groundwaters of the GAB before letting them flow uncapped along open bore drains, has also been described (e.g. Hoch 1990). But, as we will show, the exploitation of the GAB as a source of agricultural water, although first used in central western QLD in 1887, was not adopted on Wellshot until several years later, post-dating the massive expansion of sheep flocks in the region generally, and certainly on Wellshot. It, and its sister properties, proved highly profitable using a variety of property and stock management techniques that were predicated on the construction of various types of surface water management infrastructure alone.

In this paper we describe one example of the surface water management technology developed on Wellshot prior to the advent of steam-powered drills that tapped the GAB. We also then look at why these prodigious achievements in flock size and

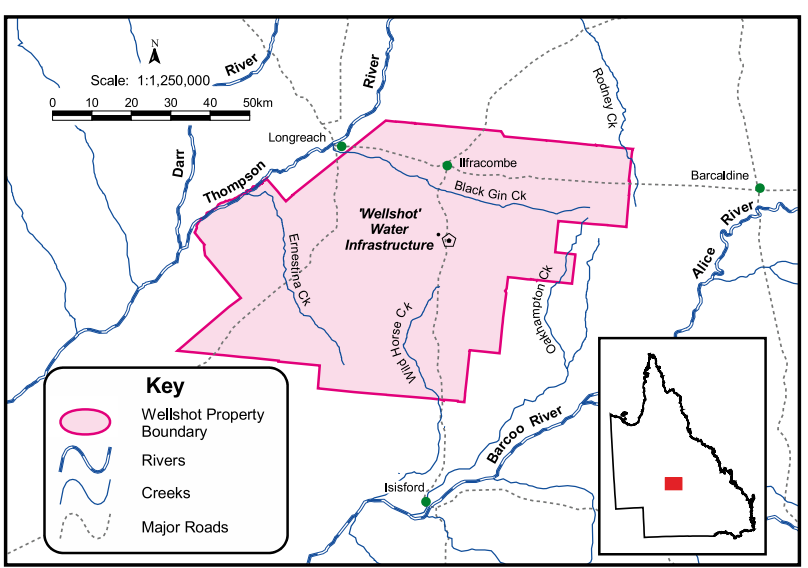

Figure 2 General location and extent of Wellshot Station showing the location of the major named waterways.

stocking rates were never repeated during the subsequent history of the station.

\section{Environmental Background}

The GAB extends across a huge area of eastern, northern and central Australia. Its recharge zone lies on the Dawson River in the Fitzroy Catchment of central QLD. It ranges across central western QLD, north to lower Cape York, west to Mt Isa and into the southern half of the NT, the northern Lake Eyre Basin, northern SA and across northwestern NSW (Figure 1). Thousands of megalitres of groundwater are pumped from it every day to provide water for the sheep and cattle stations that constitute the major economic activities across this vast region. Indeed, in many areas it seems it is only the availability of GAB water that makes these industries economically viable.

Wellshot is situated near Ilfracombe, on the eastern side of the Mitchell Grass Downs (MGD). This biogeographic zone covers an area of $257,353 \mathrm{~km}^{2}$ of central western and northwestern QLD and continues across the Barkly Tablelands of the NT. Major Thomas Mitchell (1848) was the first to describe the MGD during his explorations along the Barcoo and Alice Rivers in 1846 . He was impressed by the obvious pastoral potential of the region, referring to its 'almost boundless plains ... this Eldorado of Australia ... forming the finest region I had seen'. His lieutenant, Edmund Kennedy (1852:242), agreed with him, noting 'This is undoubtedly the finest country I have seen in Australia, the splendid reaches of water in every bend of the river, and the exquisitely green plains'.

Stanton and Morgan (1977, as cited in Border and Rowland 1990:4), in somewhat less flamboyant terms, described the MGD as:

A region composed of undulating erosional plains ... Soils are heavy clays, predominantly grey or brown with a self-mulching surface ... or brown and red with surface stones derived from relict silcrete capping ... The vegetation is dominated by arid tussock grassland (Astrebla spp.) with trees generally absent.

The climate of the MGD can be described as one of high temperatures and generally low rainfall. In the easternmost sections, rainfall ranges from 400 to $500 \mathrm{~mm}$ per annum, most of which falls during the summer months, though there is a high degree of variability in this pattern (Table 1). Average 


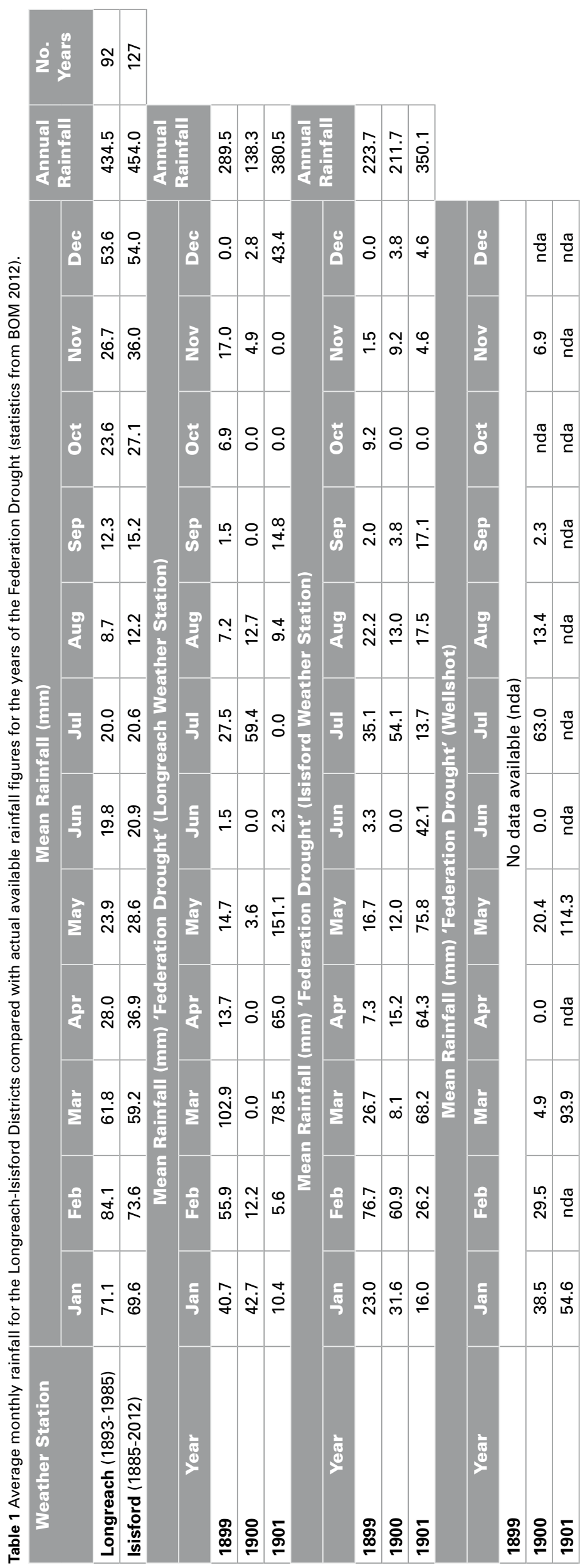

temperatures in the east hover around $30^{\circ} \mathrm{C}$ in summer and $15^{\circ} \mathrm{C}$ in winter. Not surprisingly, evaporation rates exceed $2000 \mathrm{~mm}$ per annum (i.e. four times the average annual rainfall) and rise even higher in the western MGD.

The major rivers and creeks that cross the region run only after major rainfall events in the summer months. Owing to the combination of the generally low relief of the MGD plains and the anastomosing nature of the rivers, vast areas are inundated during flood events. Other than at these times, however, the only permanent water is to be found in waterholes and billabongs along the larger watercourses.

Only a few substantial rivers are found in the eastern MGD, wherein Wellshot is situated (Figure 2). These include the Barcoo River, which flows westerly through Blackall and Isisford to join with the Thomson River at Windorah, forming Cooper Creek and ultimately flowing into Lake Eyre. The Alice River, near Barcaldine, is a tributary of the Barcoo. The Thomson River itself flows in a southwesterly direction through Longreach. The only other watercourses of any note include Aramac/Rodney, Black Gin and Ernestina Creeks, all tributaries of the Thomson, and Oakhampton and Wild Horse Creeks, both tributaries of the Barcoo, all of which are generally dry. Other surface water is ephemeral in nature, found only after rain for short periods.

Two vital points can be drawn from these observations. While seemingly plentiful in the permanent waterholes on the few major rivers, surface water is only available over much of the region as an ephemeral resource, usually (but not with any great certainty) during summer and the early months of autumn. On country without any water management infrastructure (such as dams) to capture and conserve surface water during those months when no rain falls, the critical factor influencing stocking rates is the distance cattle or sheep can travel from a watersource to feed before having to return to drink every day or two. Without surface water, the total amount of fodder available on a property is largely irrelevant to the stocking equation. Thus, the verdant plains of the MGD could not be effectively stocked the entire year. During the dry winter months stock were limited to relatively narrow corridors less than $20 \mathrm{~km}$ wide that paralleled the few watercourses with permanent waterholes, and stocking rates had to be held to a level that could be sustained on the feed available in these corridors. This fact profoundly influenced the geographical distribution of pastoral properties, their management strategies and stocking rates in the eastern MGD until the 1880s. It was the development of sophisticated surface water management infrastructure, drawing on substantial injections of capital to fund it, that overcame this limitation to pastoral expansion in this part of the MGD. Thereafter, the game became a more complex one of balancing water, fodder and stock numbers, along with the adoption of innovative 
stock management strategies, such as fencing, but also including in later years the use of rail and truck transport.

\section{Historical Background}

It took less than two years for pastoralists to seize the opportunities in central QLD that Leichhardt (1847) and Mitchell (1848) described, with stations being established along the Dawson River and thence north to Rockhampton (Gracemere Station being taken up in 1855), and in the Roma region from 1848. The grazing push west and northwest from these areas was somewhat slower. Even while the search for Burke and Wills was going on in 1861, the Mitchell District was proclaimed for pastoral settlement. Bowen Downs was taken up first in 1862, and Barcaldine Downs, Mount Enniskillen and Nive Downs in 1863. The comments made in April 1862 by Bourne (1863), a member of Landsborough's expedition in search of Burke and Wills, are of some interest in this context:

\footnotetext{
... we got away from the river into the back country ... very open downs ... much barley grass ... no water back from the river ... several watercourses which could be easily dammed, and down which water must flow in the wet season.
}

Thus, the need for water infrastructure to effectively exploit the pastoral potential of the region was obvious from the very first.

Although central QLD is now firmly at the heart of the Australian beef industry ${ }^{3}$, it was for many years dominated by sheep. In parts, principally large portions of the eastern MGD and west to Winton and Kynuna, this is still the case: the fine, open plains clear of spear grass are ideal sheep country, notwithstanding the limited availability of surface water. The first pastoralists arrived with their sheep, some pushing them overland from the New England Tablelands in the mid-1860s (Forrest 1988). Rodney Downs, to the north of Ilfracombe, was taken up by the previously successful and wealthy squatter John Eales, while the area that eventually became Wellshot (to the south) was ignored. This seems to relate directly to the apparent availability of water: Rodney Creek had been seen by the explorer Walker in the wet summer months of 1861-1862, while it was widely recognised that the Wellshot area was largely devoid of sources of surface water.

The drought of 1864 soon disabused Eales of any notions that Rodney Creek would provide permanent water for his stock, as well as further suppressing interest in the Wellshot area. Portland Downs, with its extensive frontage on the Barcoo River, was taken up in 1865 and some 39,000 sheep were depastured on its 75 square miles. Beaconsfield, another large station further to the north, had been created by the aggregation of various blocks in 1872. It remained undeveloped and largely unused until acquired by the Fairbairn family ${ }^{4}$ in 1882 . By the turn of the century they had converted this property's fortunes: it covered an area of nearly 500 square miles and carried more than 100,000 sheep.

With apparently good acreage becoming scarce in the region, the land that became Wellshot, the station to dwarf all others

\footnotetext{
${ }^{3}$ The Gracemere cattle yards, near Rockhampton, are the largest in the Southern Hemisphere.

${ }^{4}$ The Fairbairn family acquired numerous other properties throughout central OLD and became one of the leading property owners opposed to the shearers in the great strike of 1891 (Svensen 1989). Fairbairn Dam, near Emerald, is named after them.
}

in central western QLD, was acquired. It was created through A.B. Buchanan's acquisition of 66 separate runs in 1873 on behalf of Scottish investors operating as the New Zealand and Australian Land Company. The property comprised 1841 square miles (an area measuring ca $80 \mathrm{~km}$ east-west and $65 \mathrm{~km}$ north-south), with some of the western boundary including the eastern bank of the Thomson, and its southern boundary bordering Portland Downs on the Barcoo (see Figure 2). This river frontage was critical, at least during the inception of the property, to provide permanent water when the ephemeral resources, always greatly limited on the property, had dried. The method of property management used prior to the establishment of surface water management systems across the property is depicted in Figure 3.

We are fortunate that there are reasonable records available for much of Wellshot's history and these are presented here in some detail as a context for consideration of the water infrastructure necessary to sustain an operation of the size and complexity of Wellshot ${ }^{5}$. Table 2 provides a summary of the following account.

By March 1874, Wellshot was carrying 16,034 sheep and returning a profit to its owners. The flock had increased to 37,278 in 1875 through relocation of sheep from the company's Chinchilla holdings. This climbed to 60,951 in the following year, but dropped to 40,571 in 1879 . The scarcity of surface water across much of Wellshot required the owners to acquire land with river frontage (though whether this included the Barcoo as well as the Thomson is a matter of dispute).

The situation clearly being high risk and unstable, other measures were needed. In 1880 a report by John Turnbull advised the company that, for the investment of $\mathfrak{k} 50,000$ in fences, buildings and water storage, Wellshot would be able to carry 400,000 sheep. The absence of water across much of the property was identified as the most pressing problem and rectifying this would consume a large part of the funds authorised for its improvement. He noted that water might be plentiful in the Thomson, but the logistics of shifting the flock, and the speed with which the sheep would eat the limited pasture in proximity to this near-permanent water-source, made this unviable as a long-term solution, though certainly it was one element in the management strategy. With profits 'conservatively' estimated at

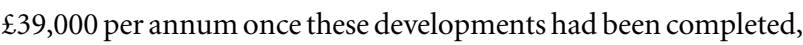
the property owners eagerly endorsed Turnbull's proposals.

Construction proceeded on a series of 20 large dams to be completed by 1882 , allowing them to depasture 200,000 sheep in March of that year. Additional smaller dams were to be built between these major reservoirs to allow even larger numbers to be stocked. Fencing was an integral element of the overall strategy. The flock was to be kept near the smaller dams while feed lasted, and then allowed to congregate around the feed and water at the larger dams, with a final option being use of the river frontage that was available. In this way the emphasis was shifted to the availability of feed as the critical element in stock management, albeit with water important but its availability now controlled through the use of constructed facilities. The confidence in such facilities to provide water for the Wellshot flock can be seen in the company's decision to sell its Haughton Vale holding on the Barcoo River, with its near-permanent waterholes, in 1884.

\footnotetext{
${ }^{5}$ We acknowledge the free use we have made of Forrest's (1988) excellent account. We have, however, taken the data he provides and used them for analysis not undertaken by Forrest.
} 
It seems this source of water was not seen as vital or integral to the plans for flock expansion once other plans were realised.

The water infrastructure, to be constructed by contractors and station teams, included earth dams dug by horse-drawn scoops and more sophisticated stone-faced shotovers. Labour was apparently scarce and high wages were accepted as an unavoidable cost if the ambitious targets were to be achieved. Initially, it was also planned to create two sheep washes to degrease the wool and so reduce transport costs (by as much as $50 \%$ by weight), but it seems these were never constructed. Neither was a steam-powered scour installed, although it had been mooted.

By December 1883 it was deemed safe to increase sheep numbers to 240,000 , with the flock effectively being run on only half the station. Previous stocking rates were also reviewed and an upwards revision to 500,000 was seen as viable once all improvements had been completed. The 20 large dams were completed in March 1884, with not even the drought of that year slowing progress. It did have an impact on flock size, however, with at least 84,000 sheep dying. There also was a significant drop in both lambing rates and the size of the wool clip. Anecdotal evidence indicates that it was a close-call - the property was nearly dry when rain saved what remained of the flock from certain destruction.

Reports, however, were still sanguine: the water infrastructure meant that Wellshot had fared better than its neighbours in the trying circumstances. Drought-proofing was seen as a definite possibility, to be guaranteed by a further nine dams constructed in that year. Furthermore, all dams were to be improved by constructing by-washes to minimise bank erosion. Other plans included using wind-driven pumps to move water from the dams to troughs to further minimise damage caused by stock trampling and to allow pastures some relief.

By 1887 the property had largely recovered from the 1884 drought, with some 109,201 lambs marked. The flock continued to expand, reaching 325,000 in 1890 . In that year more than 300,000 acres were resumed under provisions of the Land Act of 1884, but skilful negotiations with the government reduced the impact of this by excising land in a way that minimally affected the overall management strategy and stocking rate, and thus had little effect on overall profitability.

Although experiments had begun earlier in NSW, in QLD the first successful bores were sunk to tap the GAB in 1887. The QLD government provided money ( $£ 1219)$ for a bore at Barcaldine and good water was struck at a depth of $691 \mathrm{ft}(225 \mathrm{~m})$ in December of that year (Hoch 1990:31), generating considerable interest. Indeed, it was reported that the manager from Wellshot came to town and inspected the Barcaldine bore. Nevertheless, the costs of drilling were very high, success uncertain and equipment failure necessitated abandonment of a well reasonably often. For instance, the Coombe Martin bore was sunk to a depth of $1190 \mathrm{ft}$ at a cost of $£ 2500$, when the equipment failed and the bore was abandoned (Hoch 1990:32). This apparently gave the thrifty Davidson, manager of Wellshot at the time, pause for thought in his report of 1890: surface water management would suffice on Wellshot for the time being. In the meantime, the Wellshot flock expanded to 405,509 sheep depastured on 798,240 acres in March 1892, and this increased to 460,000 after a successful spring lambing. The largest number of sheep ever shorn on
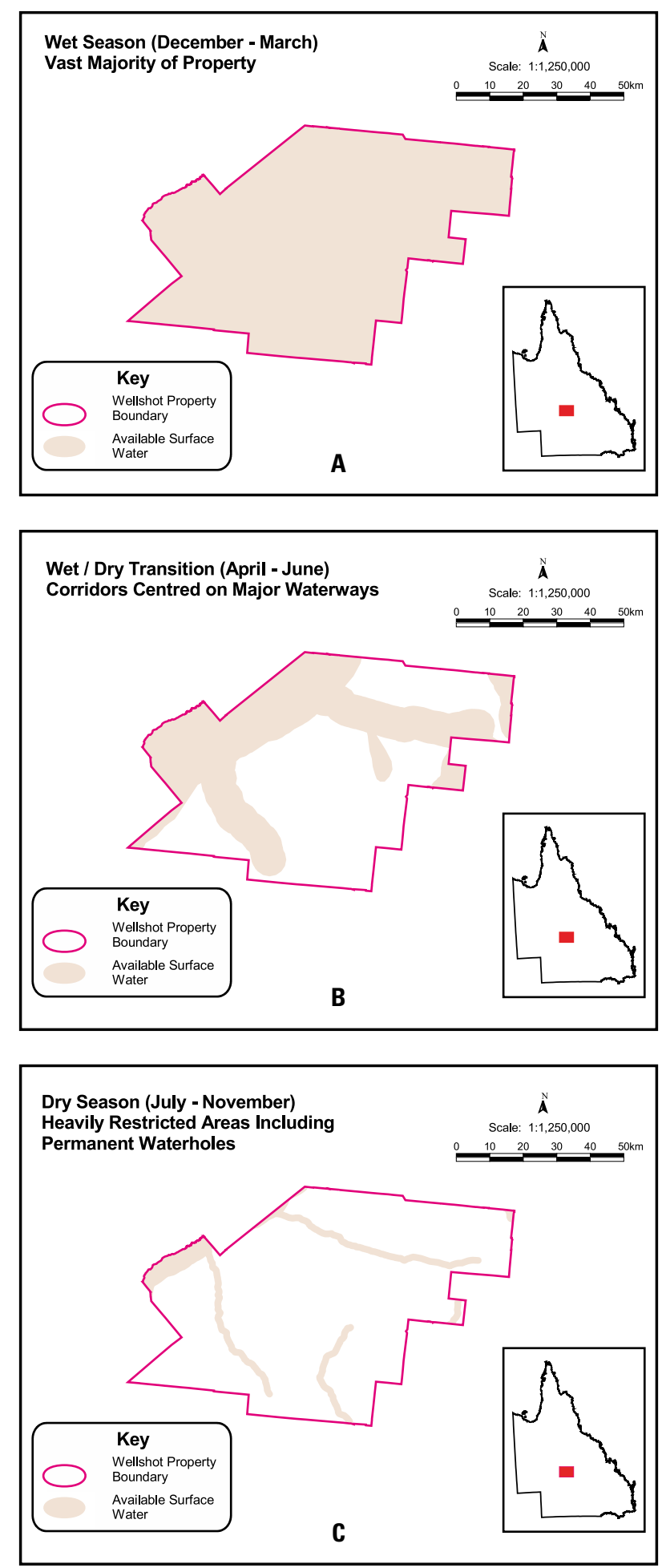

Figures 3a-c Generalised schema of areas available for stocking prior to the establishment of surface water management systems across Wellshot Station.

Wellshot was recorded in 1891 , with 425,000 passing through the shed ${ }^{6}$. This was the high point of the property - it was never again to achieve this level.

\footnotetext{
${ }^{6}$ More sheep were shorn on nearby Milo Station $(510,000)$ in 1891. Forrest (1988:61), however, noted that this included sheep from other stations driven there for shearing: they were not bred on the property. Thus, Wellshot holds the record for the largest number of sheep shorn from its own resources.
} 
Expenditure for drilling bores on the property was not authorised until late 1892. The impetus for this was the onset of a drought: 71,000 sheep died, another 75,000 had to be sold, 100,000 were put out on stock routes in January 1893, and 1600 rams were agisted by the newly constructed railway line to Emerald, $300 \mathrm{~km}$ to the east. This was another management innovation, made possible because the western railway line from Rockhampton had been extended to Ilfracombe in 1891 . In future years even greater use was made of this possibility during drought events. The purchase of properties to the east also allowed limited application of a strategy of moving stock from property to property as conditions dictated.

In March 1893 water was struck at $3500 \mathrm{ft}$, with a flow of 250,000 gallons (1125 ML) per day. Construction of bore drains and piping to transport water around Wellshot proceeded apace, while a further two bores were sunk in 1893-1894. This technology allowed even greater flexibility: groundwater could be piped pretty much anywhere, and the fodder that was otherwise unavailable once again became a management option. By 1895 flock numbers had again reached 400,000. We might care to take the view that, while the bores did not allow greater numbers of sheep, they perhaps allowed the property to recover more quickly from the ravages of drought.

Again, optimistic assessments were offered that the property, with its three bores and 49 dams, had now achieved droughtproof status: the permanent and apparently limitless quantities of groundwater from the GAB seemingly made all things possible. However, these hopes were demolished by the drought of $1899-1902^{7}$ : by early 1902 , in the complete absence of any fodder, stock numbers had fallen to only 60,000 . Although the flock recovered reasonably quickly through natural growth and purchases, Wellshot never again approached anything like the figure of $>400,000$ seen in the late 1880s and early 1890s, with a second resumption of 200,000 acres in 1903 putting a much lower ceiling on gross stock numbers, if not on the stocking index.

We now turn to a consideration of pre- and post-GAB bore stocking rates, drawing on data presented in Table 2. The figures used here have been taken from Forrest (1988), although he did not summarise them in this way, nor analyse them as we do. Various points should be noted in relation to this table. The stocking index is simply the size of the property in acres divided by the number of sheep stocked. Thus, the lower the stocking index, the greater the number of sheep per acre. This seems a more reasonable measure of effective property management than simple stock numbers, particularly when the impact of land resumptions on total stock size is taken into account. In the absence of any data that the property increased in size between 1873, when first aggregated, and 1879, when the first estimate of its size was made, we have used the 1879 figure for the stocking index both before and after that time, up to the 1890 land resumption. The property area from 1890 through until the 1903 resumption is uncertain, with a discrepancy of about 12,000 acres - both totals derive from Forrest. The higher figure is Forrest's direct statement of the property size at that time. The lower figure has been calculated using the size of the property following the 1903 resumption, to which has been added the acreage Forrest noted was lost in this resumption. We have used

\footnotetext{
This is commonly called the Federation Drought as it straddled the creation of Australia as a federated nation in 1901.
}

the higher total in calculating the stocking index as this gives the more conservative stocking rate but the overall effect, given stock numbers, is minimal. No direct figure on the property size is available for post-1903, but Forrest noted that it decreased by $25 \%$, so we have subtracted this when calculating acreage.

Some of the figures on flock size were calculated by subtracting reported deaths from flock size reported for the previous year. The 1887 flock numbers have been calculated using the successful lambing figure and simply doubling it, assuming that every ewe conceived and dropped. This is likely to be a conservative estimate of flock size, as a lambing rate of only $80 \%$ - as against the $100 \%$ we have used - would give a total flock closer to 245,000 , not taking rams into account. Before the turn of the century lambs were not shorn and so the total number of sheep shorn for 1891 represents a conservative estimate of the flock for that year. We have used the lower figure for the 1892 estimate as this seems more reasonable for the full year. Again, for 1893 we have used the lower figure from 1892 and subtracted sales and deaths to obtain the stock index. Data for 1895 are simply an estimate given in Forrest, while 1924 is an estimate given to Forrest in the 1980s by the son of the then-property manager in an interview, as is the figure for 1925.

Various observations can be made about the stocking index. The first is the obvious impact and effectiveness of the property developments, and particularly surface water management infrastructure, constructed between 1880 and 1884. Prior to 1880 , in those years when only natural sources were used, stocking rates were never better than one sheep for every 20 acres. Post- 1880 this rose to better than one sheep per 5 acres, and only dropped to one sheep every 7.56 acres in the drought of 1883-1885, despite the loss of river front acreage on the Barcoo following the sale of Haughton Vale. Thus, naturally available surface water had measurably and quickly become a minor element in the overall property management strategy.

Continued improvements in the stocking rate were achieved through the late 1880s and into the early 1890s. Wellshot reached its peak in flock size, and the best stocking index, in 1891 - two years before any GAB bores were drilled on the property. This may partly be an aberration induced by stock numbers being retained after the resumption at levels that would only have been countenanced before the resumption - that is, the property was simply overstocked. It is, however, evident that the stocking index was trending in that direction anyway. Moreover, the property was under the control of experienced managers equipped to judge whether they should take the risk of sustaining historically high stocking rates.

The drilling of bores on the property did not see further increase in the stocking index. The apparent effect of the bores was to improve stock maintenance rates during the drought of 1892-1893, possibly sparing the property from the worst, and it may have improved the speed of recovery. But this was seemingly a rather marginal improvement in the longer term, given that in the drought of 1899-1902 the overall stock numbers dropped below those of 1885 .

Of course, we have not factored in the relative severity of these droughts. It does seem that the Federation Drought was the severest in its longevity (Table 3 ), with catastrophic overall effects. It is quite clear that, in this extended drought, access to artesian sources of groundwater made the property no more 
drought resistant than it had been previously. No matter how much water was available, stock rates could not be maintained in the absence of fodder. In this respect, the property was in the same position as in the mid-1880s, while of course there were still limits to where water could be stored or carried on the property irrespective of how much was available at the bore head. Ultimately, the availability of fodder once again became the dominant factor in the stocking equation in a long drought, so that without rain there was no fodder growth and the sheep starved. Thus, management decisions taken in 1880, and the water infrastructure constructed in the following four years, had seen them reach the optimum and premium levels of production that could be achieved on this property. The restrictions on stocking rates and flock size imposed by the absence of surface water across the property as a whole until the early 1880 s were broken by management decisions taken in those years, but not by those made later.

We also note that the loss of 380,000 acres in 1890, reducing the property by one-third, had no appreciable impact on the effectiveness of stock management, at least when measured by gross stocking rates. Despite this reduction in acreage, the property was able to improve its stocking index for the next couple of years and then maintain that rate thereafter in the face of further resumptions. This is testimony to the effectiveness of the infrastructure, created in the early 1880s, in ensuring that most, if not all, of the property could be stocked, irrespective of distance from naturally available water-sources. The skill of the company managers in their negotiations with government officials prior to the resumption probably also played some part.

\section{Archaeological Description}

There are various archaeological features on Wellshot that we describe here, including: a major piece of water management infrastructure commonly called the Shotover; a Cobb and Co staging post; and a short section of old road (all shown on Figure 4); some sections of corduroy road; and a cemetery near the main homestead in which some South Sea Islanders are buried (Figure 5). The dominant feature is the Shotover, and

Table 2 Summary of Wellshot property history, acreage and stocking rates.

\begin{tabular}{|c|c|c|c|c|}
\hline Year & Flock Size & $\begin{array}{l}\text { Property Area } \\
\text { (acres) }\end{array}$ & Comments & $\begin{array}{l}\text { Stocking Index } \\
\text { (acres/sheep) }\end{array}$ \\
\hline 1874 & 16,034 & $1,178,624 ?$ & $\begin{array}{l}\text { Property created by aggregation of } 66 \text { runs; property probably } \\
\text { this size }\end{array}$ & 73.51 \\
\hline 1875 & 37,278 & - & - & 31.62 \\
\hline 1876 & 60,951 & - & - & 19.34 \\
\hline 1877 & - & - & Property dealings - temporary change of ownership & - \\
\hline 1879 & 40,571 & $1,178,624$ & Property reverts to company & 29.05 \\
\hline 1880 & 38,376 & - & $\begin{array}{l}\text { Plan to expand to } 400,000 \text { sheep; construction of water } \\
\text { infrastructure commences }\end{array}$ & 30.71 \\
\hline 1882 & - & - & 50,000 sheep brought from Riverina to property & - \\
\hline 1883 & 240,000 & - & Drought commences & 4.91 \\
\hline 1884 & - & - & $\begin{array}{l}\text { Drought continues; Haughton Vale (providing Barcoo frontage) } \\
\text { sold by company }\end{array}$ & - \\
\hline 1885 & $156,000 ?$ & - & Estimate $-84,000$ sheep die in drought & 7.56 \\
\hline 1886 & - & - & Drought breaks & - \\
\hline 1887 & $220,000 ?$ & - & $\begin{array}{l}\text { Probably an underestimate }-109,201 \text { lambs marked that year } \\
\text { suggesting at least same number of ewes }\end{array}$ & 5.36 \\
\hline 1890 & 325,000 & $\begin{array}{l}798,240 \\
786,654\end{array}$ & Land resumed - Forrest's figure inconsistent & 2.46 \\
\hline 1891 & $425,000 ?$ & - & $\begin{array}{l}\text { Estimate - number of sheep shorn but lambs were not shorn at } \\
\text { this time }\end{array}$ & 1.88 \\
\hline 1892 & $\begin{array}{l}405,509 \\
460,000\end{array}$ & - & $\begin{array}{l}\text { Two figures - second after spring lambing; drought } \\
\text { commences; drilling of first bore in December }\end{array}$ & 1.97 \\
\hline 1893 & $\begin{array}{r}250,000 \\
-300,000 ?\end{array}$ & - & $\begin{array}{l}\text { Estimate - 71,000 sheep died and another } 75,000 \text { sold; water } \\
\text { struck in bore in March }\end{array}$ & 3.19 \\
\hline 1894 & 372,646 & - & - & 2.14 \\
\hline 1895 & $400,000 ?$ & - & General estimate from Forrest; three bores drilled by this stage & 2.00 \\
\hline 1898 & 378,000 & - & Property declared drought-proof & 2.11 \\
\hline 1899 & 343,517 & - & Drought commences & 2.32 \\
\hline 1900 & 210,000 & - & Drought continues $-130,000$ sheep die & 3.80 \\
\hline 1901 & 60,000 & - & Drought continues & 13.30 \\
\hline 1902 & 155,000 & - & Drought breaks - 95,000 sheep purchased for restock & 5.15 \\
\hline 1903 & 191,281 & 598,688 & Land resumed & 3.13 \\
\hline 1904 & 225,000 & 598,688 & - & 2.66 \\
\hline 1905 & 275,000 & - & - & 2.18 \\
\hline 1917 & 225,000 & $449,016 ?$ & Estimate of area based on further resumption of $25 \%$ of area & 2.00 \\
\hline 1924 & $200,000 ?$ & 449,016 & Estimate from oral testimony & 2.25 \\
\hline 1925 & 40,000 & - & Drought - large numbers of stock agisted by train & 11.23 \\
\hline
\end{tabular}




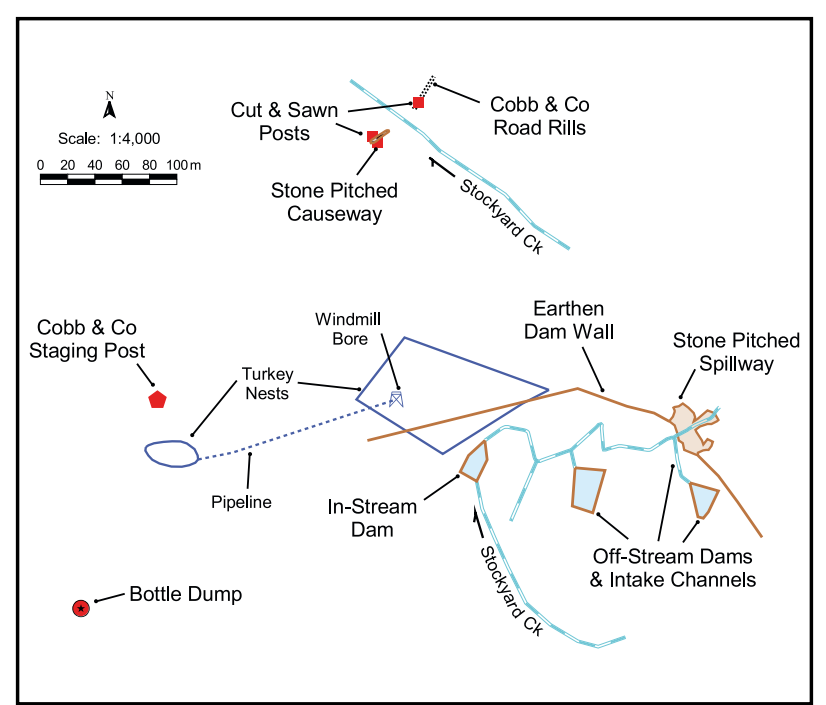

Figure 4 Archaeological features found in the area of the Shotover.

it is this feature that relates expressly to the water management strategy in which we are particularly interested.

\section{The Shotover}

The Shotover is situated on a waterway locally known as Stockyard Creek. It is comprised of three distinct elements. The first is a spillway that consists of well-preserved pitched stone abutments and downstream splash area (Figure 6). The second is an earthen wall extending both sides of the spillway, totalling $260 \mathrm{~m}$ on the western side (where it fronts the creek) and $80 \mathrm{~m}$ on the eastern side. The toes of the wall are also constructed of pitched stone, with a length of $340 \mathrm{~m}$, a width of ca $10 \mathrm{~m}$ and height of $3 \mathrm{~m}$. There is ca $7800 \mathrm{~m}^{3}$ of earth in the wall.

There are three excavated ponds, one situated on the natural channel of Stockyard Creek, and another two connected to the natural stream by excavated channels (Figure 7). The ponds have a combined surface area of $1200 \mathrm{~m}^{2}$ and, with a current minimum depth of ca $3.5 \mathrm{~m}$, would have held $4200 \mathrm{~m}^{3}$ of water (4.2 ML). A series of channels were dug upstream of the spillway, two of which were placed to direct stream flows from the creek into the two off-stream ponds. The purpose of the third channel is unclear, but it was perhaps designed to channel water around into the broader impoundment area formed behind the earthen

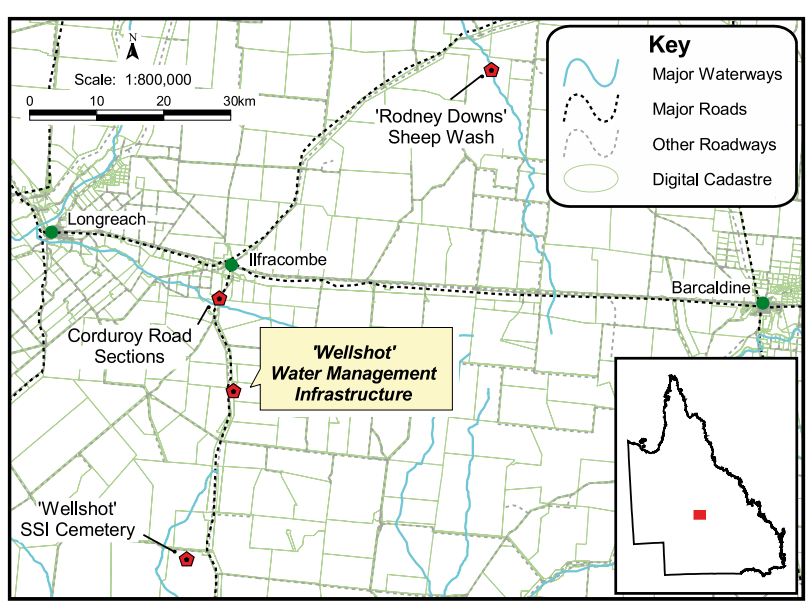

Figure 5 Location of other archaeological features discussed in the text.

wall, or back upstream of the on-stream pond, or perhaps another pond was planned but not dug. These channels total at least $100 \mathrm{~m}$ in length and are typically $1.5 \mathrm{~m}$ in depth, and approximately $3.5 \mathrm{~m}$ in width. The cross-section of the channels and the shape of the ponds indicate that they were dug with horse-drawn scoops.

The Shotover is generally in good condition, except for a section of the earth wall that has been destroyed or incorporated in to a more recent 'turkey nest' dam associated with a bore. A concrete pipe has also been laid into one of the ponds from the turkey nest not so long ago. The pitched stonework is in excellent condition. The stone used in the pitching has been brought to the site from a location at some remove, because there is no obvious local source. At a later date, someone has also concreted a portion of the pitched stone area, possibly for use as a crossing point on the creek.

The method of operation of the Shotover appears to have been as follows. The earth wall caught water flowing downstream during flood events, causing it to spread out over a large impoundment area of lower-lying country upstream of the wallthe total area of impoundment can only be roughly estimated at this stage, but would conservatively cover some $60,000 \mathrm{~m}^{2}$ (6 ha) of the area immediately upstream of the Shotover. The pitched

Table 3 Periods of extended drought in the Longreach area between 1893 and 2004 (after Phelps 2007:14). Note that 'severe' drought refers to the driest $5 \%$ of years for each 24 month period.

\begin{tabular}{|c|c|c|c|c|}
\hline Drought & Period & $\begin{array}{l}\text { Duration } \\
\text { (month) }\end{array}$ & $\begin{array}{l}\text { Total Rainfall } \\
\text { (mm) }\end{array}$ & $\begin{array}{c}\text { \% Time in } \\
\text { 'Severe' Drought }\end{array}$ \\
\hline 1 & March 1898 - January 1904 & 71 & 1395 & 46 \\
\hline 2 & March 1913 - June 1916 & 40 & 840 & 35 \\
\hline 3 & March 1918 - April 1920 & 26 & 607 & 0 \\
\hline 4 & February 1925 - August 1931 & 79 & 1705 & 23 \\
\hline 5 & January 1934 - February 1936 & 26 & 585 & 33 \\
\hline 6 & April 1937 - September 1939 & 30 & 532 & 14 \\
\hline 7 & July 1944 - July 1947 & 37 & 793 & 14 \\
\hline 8 & May 1965 - January 1968 & 33 & 648 & 10 \\
\hline 9 & March 1968 - December 1970 & 34 & 748 & 64 \\
\hline 10 & February 1987 - February 1989 & 25 & 614 & 0 \\
\hline 11 & March 1991 - November 1993 & 33 & 590 & 40 \\
\hline 12 & January 2001 - December 2003 & 36 & 706 & 31 \\
\hline
\end{tabular}




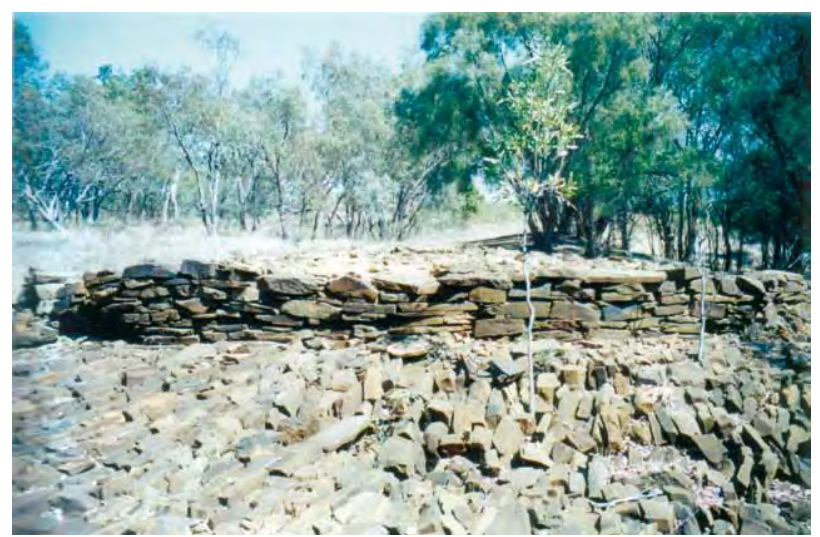

Figure 6 Stone pitched spillway and abutment.

stone spillway allowed excess water to escape downstream during peak flood events, while minimising erosion of the wall and the streambed. Similarly, historical accounts document that the pitched stone found on the toes of the wall minimised erosion at these times, while allowing excess water to escape around the ends. The channels directed water from the creek-line into the ponds, which served as reservoirs during periods of natural low stream flow, and once the relatively shallow water captured behind the earthen wall during flood events had been used or had evaporated. The channels, too, would have held water for some time after supplies in the larger shallow impoundment had disappeared. These simple expedients would have extended the period of time over which stock could be depastured at this location. With the high evaporation rates in the region and water in the impoundment area having a depth of not more than 3 to $5 \mathrm{~m}$, any means of extending the operational capacity of the facility were to be welcomed. Otherwise, undepleted forage would have been abandoned because of the absence of water. This proposed method of operation of the Shotover is depicted in Figure 8.

\section{Section of Old Road with Guide Posts}

This, too, is situated on Stockyard Creek. There are two axe-cut gidgee posts at the southern end of the section of road, with one on either side of the road. There is another guide post at the northern end, but this is saw-cut. On the northern side of the creek there are two clear rills marking either side of the road. These run from the edge of the creek for a distance of ca $40 \mathrm{~m}$. The sawn post sits right on the eastern rill. The rills appear to have been created using a grader blade. There is no rill on the south side of the creek. There is, however, a small patch of pitched stone approximately $20 \mathrm{~m}$ in length. The presence of the axe-cut posts and pitched stone, together with the sawn post and the graded rills, suggests that this section of road was used for an extended period of time, hence the different technologies evident in its construction and maintenance.

\section{Cobb and Co Staging Post}

There are only a few remnants of this facility located approximately $200 \mathrm{~m}$ to the west of the Shotover. These include a small area of paving made using stone that was possibly cannibalised from stocks stored for repairs of the Shotover and, further to the south, an extensive bottle dump that appears to have been scavenged in the past.

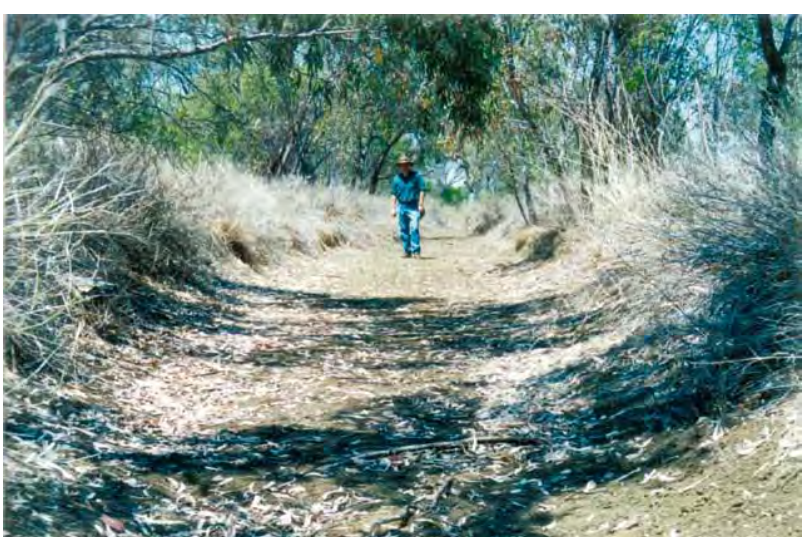

Figure 7 Channel excavated to feed off-stream storage dam.

\section{Corduroy Road Sections}

The 'corduroy' consists of axe-cut gidgee saplings situated in the northern section of the property across a heavily braided section of Black Gin Creek, approximately $13 \mathrm{~km}$ from the Shotover. Each sapling piece is approximately $4 \mathrm{~m}$ in length, and was laid side-by-side across the road to create a hard surface. In two cases, the corduroy has been laid next to the creek where the roadway apparently ran parallel to it, while in another three instances it has been used as part of a creek crossing and runs down into, or actually is in, the creek. Four sections have a combined length of $21 \mathrm{~m}$. A fifth section, with about $9 \mathrm{~m}$ of corduroy, represents the most sophisticated piece of work seen. Here the corduroy has been laid across the creek, with two uprights placed along its western side to support larger logs that seem to have acted either as a protective buffer, or perhaps as a guide when the creek, which was mostly dry during our visit, was flowing or flooded.

\section{South Sea Islanders' Cemetery}

There are two cemeteries situated at the main Wellshot homestead about $25 \mathrm{~km}$ to the south of the Shotover. One of these contains several formal engraved wood and stone grave markers and surrounding barriers dating to the 1880s. Adjacent, but quite separate, is a second cemetery. Although no identifiable individual burial areas or grave markers are today evident, several sources (both anecdotal and published - see below) are clear that this cemetery was used for non-European workers, and specifically South Sea Islanders, on Wellshot. The area is delineated by the remains of a sapling post and single rail fence and measures some $10 \mathrm{~m}$ by $8 \mathrm{~m}$.

\section{Discussion}

We now wish to turn to four separate issues: the dating of the construction of the Shotover and its purpose; who might have been involved in its construction; and the wider implications emerging from the rapid and profitable expansion of the sheep industry during the 1880 s that was made possible by use of water management technology of this sort.

\section{Date of Construction}

We can discern three distinct phases of property development: pre-1880 when no water infrastructure was established; 1880-1893, when large-scale development of surface water infrastructure took place, particularly in the period 1880-1884; and post-1893, when groundwater bores had been drilled to 

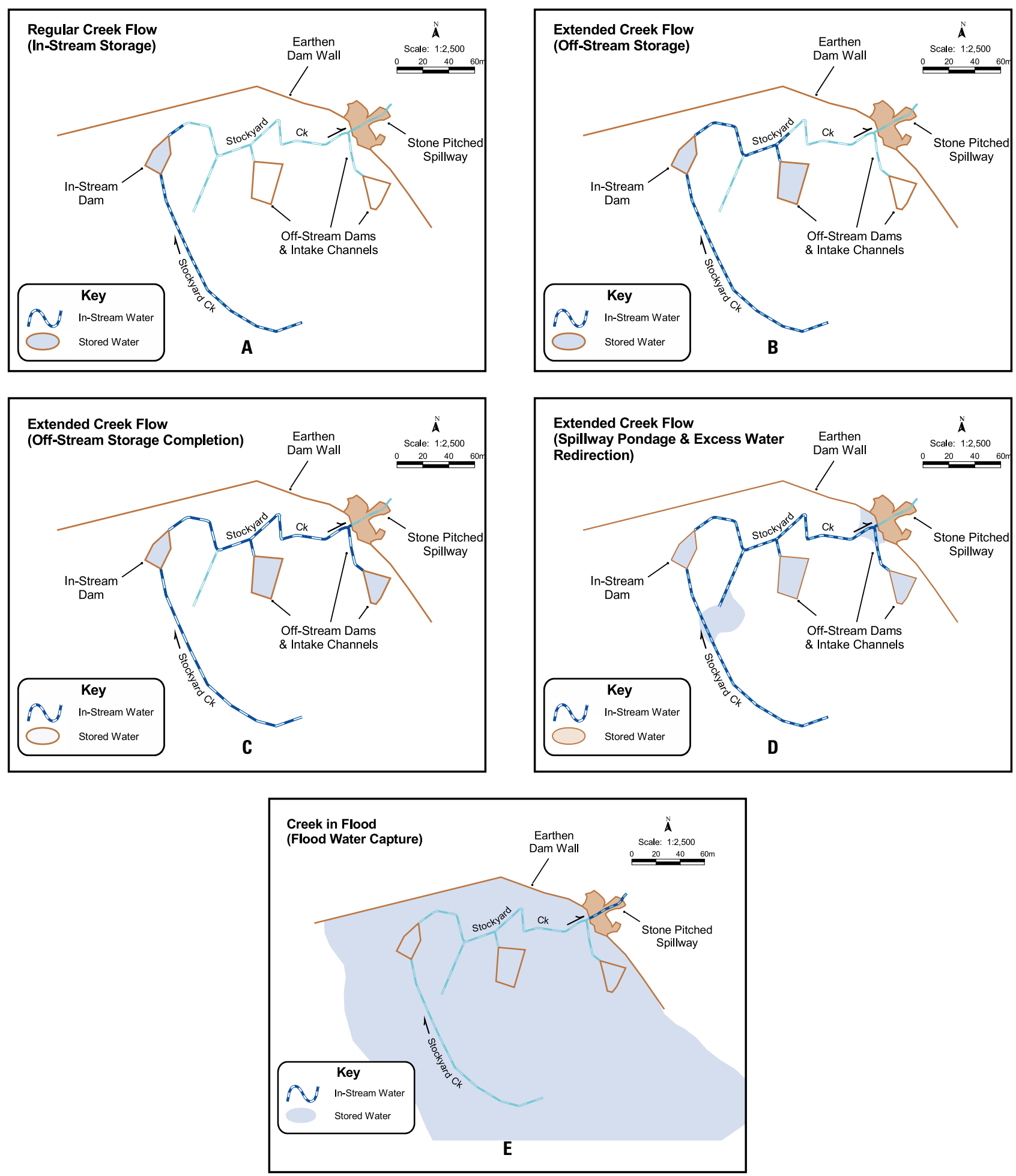

Figures 8a-e Putative modelling of operation of the Shotover. 
the GAB. These phases are summarised in Table 4, along with their likely archaeological signature. Each phase had a very different plan for water use and thus distinctly different water infrastructure requirements, and this will have affected the resulting archaeological signature of each phase.

Prior to 1880, primary use was made of natural water sources: temporary creeks and waterholes across the plains during the wet season, and the river during the dry season. Consequently, there is little signature of this period to be found.

From 1880 to 1893 , the construction of dams and shotovers in the early years, with some wind-powered pumps and troughs in the later years, took place. The dams were dug using horsedrawn scoops (Forrest 1988:55). These dams continued to be used in later years, and possibly were further developed after diesel-powered machinery, such as bulldozers, became available. The wind-powered pumps also are likely to have subsequently been replaced by diesel and electric pumps, and the early wooden troughs largely replaced with concrete and corrugated iron versions. The stone-faced shotovers, however, are less likely to have been modified, though they could well have been destroyed if they were in the way of later property development programs. The construction of the turkey nest, and its impact on the dam wall at the Shotover, is a limited demonstration of this sort of activity.

After 1893, the water infrastructure would include the bore heads themselves, turkey nests to store water at the head, extensive open bore drains to transport water around the property using gravity, possibly some pipe sections where topography did not allow gravity fed open drains, and troughs and dams to hold water from the bore drains. Initially, the bore heads were uncapped and flowed freely. In recent years, they have been capped to conserve water from the GAB, but more bores have been sunk with tanks built at each, or with piping to other water points, so open bore drains are less common (and the huge losses through evaporation have been reduced). The bore drains were relatively shallow features, ploughed along surveyed lines to ensure water flow by gravity to outlying points. They were either re-ploughed or cleaned by shovel to prevent siltation inhibiting flow, and in later years graders were used for this purpose. As Wellshot was dismembered by continuing resumptions after 1890 , it is likely that new bores and drains would have been established to service new paddock systems. The drains are probably not very clear now, but possibly some might be identified and plotted using low-level oblique aerial photography.

Based on this tri-partite development model, the Shotover, in all probability, was constructed prior to 1892 , and most likely as part of the initial expansion of water management infrastructure undertaken from 1880 to 1884 . Various lines of reasoning point to this conclusion. First, and the most compelling, is that once drilling of the $\mathrm{GAB}$ commenced, an entirely different suite of water management features emerged. Use of the GAB does not require massive earthworks, such as the Shotover, and while continued use might be made of this feature, it is unlikely that expenditure would have been committed to this after an investment decision had been made on the drilling program. Thus, the construction of the Shotover would pre-date drilling. On Wellshot this places it as pre-1892 at the latest (Forrest 1988:60). Second, there is one reference in 1884 to plans to expand the use of pitched stonework, already used on the property, to reduce erosion around dams, thereby suggesting that such features were in existence. The Shotover includes examples of pitching designed to minimise erosion at the toes of the dam and it is not a large stretch to consider that this historical reference could include it as one of the places requiring such modification. This would place its construction as pre-1884, in a three year window prior to when investment on infrastructure of this sort was initiated. Third, the Cobb and Co Staging Post made use of stone apparently salvaged from the Shotover. This staging post was established to transport

Table 4 Predicted archaeological signatures for the major development phases at Wellshot Station.

\begin{tabular}{|c|c|}
\hline $\begin{array}{l}\text { Property Development (Water } \\
\text { Infrastructure) }\end{array}$ & Archaeological Signature \\
\hline $\begin{array}{l}\text { Pre-1880 } \\
\text { no water infrastructure was established }\end{array}$ & $\begin{array}{l}\text { - Natural water sources: intermittent creeks and waterholes across the plains } \\
\text { during the wet season } \\
\text { - Little, if any, signature of this period is likely to exist }\end{array}$ \\
\hline $\begin{array}{l}1880 \text { to } 1893 \\
\text { large-scale development of surface } \\
\text { water management infrastructure took } \\
\text { place, particularly in the period from } \\
1880 \text { to } 1884\end{array}$ & $\begin{array}{l}\text { - Dams and shotovers, with some wind-powered pumps and troughs in the } \\
\text { later years } \\
\text { - Dams were dug using horse-drawn scoops; these may have been further } \\
\text { developed with heavy machines such as bulldozers } \\
\text { - Wind-powered pumps likely to have been replaced by diesel and electric pumps } \\
\text { - Early wooden troughs largely replaced with concrete and corrugated } \\
\text { iron versions } \\
\text { - Stone-faced shotovers are unlikely to have been modified, though they could } \\
\text { well have been destroyed, using heavy equipment, if they were in the way of } \\
\text { later property development programs }\end{array}$ \\
\hline $\begin{array}{l}\text { Post-1893 } \\
\text { bores had been drilled to exploit } \\
\text { groundwater in the GAB }\end{array}$ & $\begin{array}{l}\text { - Heads for deep bores drilled to GAB } \\
\text { - } \text { - Extensive open bore drains: relatively shallow features, ploughed along } \\
\text { surveyed lines to take water around the property using gravity - reploughed } \\
\text { or cleaned by shovel to prevent siltation inhibiting flow; graders used more } \\
\text { recently for this purpose } \\
\text { - Troughs and dams to hold water from the bore drains } \\
\text { - Possibly some pipe sections of bore drains where topography did not allow } \\
\text { gravity fed open drains } \\
\text { Initially, bore heads uncapped; in recent years, capped to conserve water from } \\
\text { the GAB - bores sunk with tanks built at each, or with piping to other water } \\
\text { points, so open bore drains are less common }\end{array}$ \\
\hline
\end{tabular}


passengers to and from the new railway head at Ilfracombe. This reached Ifracombe in 1891, after which time a series of staging posts heading south was established at the Twelve Mile (the Shotover), Wellshot head station and Portland head station (Forrest 1988:156). The Shotover would certainly have existed at this time, making this location an ideal place at which to establish the staging post. Moreover, with the reliance for water now placed on exploitation of the GAB, less emphasis would have been placed on the use and maintenance of the Shotover. Presumably, this meant either that stocks of stone stored for maintenance or left over from construction could be used for other purposes, or that there could be direct cannibalism of the facility itself for other purposes. In any case, this serves as a very convenient dating tool, again dating the facility as pre-1892 and before use was being made of the GAB. We can be rather confident, therefore, that it was surface water management technology of this sort that fuelled the massive expansion of the station's stocking rate during the 1880 s.

\section{The Purpose of the Shotover}

The issue of its purpose also needs some consideration. We have described it purely in terms of a water management facility designed to allow flocks to be depastured for periods of time well beyond those that would be possible if no such facilities were in place, thereby increasing the time stock could forage in the area and thus the overall stocking rate of the property. It might have been possible also to use it as a wool scour to remove dirt from the wool, thereby reducing its weight and thus the cost of transport to export market. Similar pitched stone facilities on nearby Rodney Downs (see Figure 5) have been interpreted as such, although there seems to be no direct evidence in this regard (Huff et al. 1993:76, 157).

Various factors militate against this interpretation of the Shotover. First, while the desirability of scouring wool was wellrecognised on the property, and plans were made to provide facilities for this purpose as part of the overall expansion, there is a clear statement that none were ever constructed. Second, those plans were to provide for steam-powered equipment, not a simple washing of the fleeces in water and then spreading them out to dry. Cold washing is not particularly effective in any case, serving only to remove some dirt and vegetative matter but not degrease the wool (Cummins 1989). Third, while the area is known as Stockyard Creek, there is no evidence of any kind that suggests the construction of a shearing shed at this location. In the absence of this, any suggestion of the use of the Shotover for washing, if not scouring, would require loading the fleeces at the shearing shed, transporting them to this area, washing and drying them, and then repacking them for transport to market. Again, there is no evidence in the literature or elsewhere suggesting this possibility. In any case, it is difficult to see that the double-handling required would have been economically viable. Fourth, it is questionable whether the amounts of wool we are talking about could have been processed by hand in any case. A large, industrial-sized operation for the huge volumes at hand would seem essential. Finally, directly related to this, and setting aside the absence of any evidence of equipment for heating of the huge quantities of water at the Shotover, wool scouring was a difficult business, requiring considerable skill. Too much washing rendered the wool brittle, difficult to process and reduced its value. Large volumes of soap and other chemicals were also required. It was for this and other reasons that many property owners, after experimenting with the job, abandoned such attempts from the early 1880s onwards. Rather, their wool was transported greasy and dirty to centres where large facilities that could ensure suitable quality control would undertake the task (Cummins 1989; Pearson 1984). The Blackall steam wool scour and a further 51 others were established and operated as commercial operations early in the twentieth century in this region (including Barcaldine where the Wellshot wool might have been processed) for precisely these reasons (both Cummins and Pearson discussed the technology and the economics of the exercise in more detail). In the absence of any supporting evidence, the more prosaic suggestion that, in this case, a dam is just a dam seems the better option. This also raises questions relating to the interpretation of the facility on Rodney Downs.

\section{Who Built the Shotover?}

The Shotover is an excellent example of pitched stonework and, as such, raises the question of who undertook this work. The records indicate that both station hands and contractors were employed in the rapid expansion of water infrastructure that took place between 1880 and 1884 . It was only after 1884 , by which time major elements of the program had been completed, that a contractor was exclusively engaged to undertake this work.

Digging of dams using horse-drawn scoops, along with the erection of buildings, requires planning and construction expertise, but these were not uncommon in the region. Stone pitching of the standard seen at Stockyard Creek was, however, a rare skill, and there are few examples of it found throughout central QLD. The majority of those that are found were associated with places where South Sea Islanders were engaged as labourers, and where they could use the traditional stone pitching skills they brought with them. These include numerous stone pitched walls near Bundaberg and Mackay, and a trackway built at Yeppoon for the Farnborough sugar plantation. Is it possible that the Shotover was constructed using South Sea Islander labour?

While most people are aware of the role South Sea Islanders played in the development of QLD's sugar industry in its plantation phase, fewer are aware that in the early years of indentured labour, from 1863 to 1880 , many Islanders were taken to the hinterland to work on pastoral properties (see Evans et al. 1993). These included properties throughout central QLD - there are accounts of groups of Islanders being taken as far west as Boulia during those years and also accounts of their employment around Tambo (see Evans et al. 1993:193, 199). We also know that they were employed on Wellshot. For instance, the Register of Deaths in the Mitchell District (Tambo) recorded the deaths of six Islanders on Wellshot in 1875 and 1876. Moreover, there is the separate cemetery considered to be for Islanders near the Wellshot homestead. While overall numbers of Islanders employed in the pastoral industry decreased between 1871 and 1881, Islanders continued to be taken west from Rockhampton in 1876 and 1877.

Islander employment in the pastoral industry was curtailed by regulations set by the QLD government in 1877 . Under these regulations, first contract Islanders (i.e. those just brought to the country), could only be employed within 30 miles of the coast: after that date only second contract Islanders could be engaged 
to work on pastoral properties but, as they were unenthusiastic about working in such areas, numbers so employed dropped. The passage of the Pacific Islanders Labourers Act in 1880 formalised these regulations, and an 1884 amendment to this Act restricted all Islander employment to the sugar industry alone. General contract length was three years (Evans et al. 1993).

The Shotover on Wellshot is not the only facility of this sort in the region. As mentioned above, another excellent example is found on Rodney Downs. The construction of this example, which we have inspected, is generally attributed to Islanders (Huff et al. 1993:76). The two examples of stone pitching have certain elements in common, but there are also some significant differences in various aspects of the construction, particularly the use of wooden elements in the Rodney Downs example as part of a temporary wall to block the spillway. These differences may reflect different functions of the facilities - Rodney Downs is usually described, though perhaps questionably, as a wool scour, whereas we argue Wellshot is a shotover exclusively for water storage. It also should be noted that, while the facility on Rodney Downs is attributed to South Sea Islanders, there is no independent and direct evidence of this. Moreover, Chinese labourers engaged in the pastoral industry of this region were also known for their skills in stone pitching. The shotovers found on creeks close to the famous Combo Waterhole ${ }^{8}$, near Kynuna, are sometimes attributed to them. More detailed analysis is required to explore these possibilities.

Consequently, we cannot offer a definitive answer on who built the Shotover. Certainly, there were South Sea Islander people on Wellshot in the 1870s. Some may have continued to work there into the early 1880 s when the Shotover was probably built, and they almost certainly would have had the requisite skills. If they were involved in its construction this would probably have been towards the very end of their employment in the pastoral industry in this region. Our conclusion on this issue: there is a possibility that South Sea Islanders undertook the work, but the jury remains out.

\section{Relationship of Other Features to the Shotover}

The Cobb and Co Staging Post, section of old road and corduroy sections are all part of a single aspect of the communications history of the area: the development of a road between Ilfracombe and Isisford. The construction of this road post-dates the arrival of the railway at Ilfracombe in 1891, and thus is well after the date for construction of the Shotover, as well as the establishment of Wellshot. Prior to that time, the main travel routes through the region were either to the north across Rodney Downs to Aramac, or from the south through Tambo, Blackall and Isisford. All this changed with the arrival of the railway in Ifracombe, as the town became an important terminus for the supply of commodities and the distribution of mail to the surrounding stations, a point from which wool and stock could be transported east, and also the point from which new coach services to points north, south and west could start. Arrival of the train also opened up the prospect of the agistment of stock on properties well to the east, a management strategy that we know was utilised by Wellshot in later years.

${ }^{8}$ This is commonly seen as the site of events described in
Waltzing Matilda.
Cobb and Co moved to establish a service from Ilfracombe to Isisford very soon after the railway arrived (Forrest 1988:155). As we have noted, there were three staging posts between Ilfracombe and Isisford: the Twelve Mile (site of the Shotover), Wellshot and Portland Downs. Each staging post provided new horses for the next stage of the journey, and usually offered refreshments for purchase by the traveller. Under good conditions the trip from Ilfracombe to Isisford took 11 hours to complete. The fame and prestige of Wellshot and the other stations resulted in this route having some of the best horse stock of any Cobb and Co route (Forrest 1988:156).

Cobb and Co lost their interest in the route in 1906, when the mail contract was awarded to Ellis Sutton of Isisford. He then engaged Billy Gillespie, a driver of high standing, to drive for him. Sutton and Gillespie made transport history when, on 1 April 1910, they used a motor truck to transport the mail (Forrest 1988:157). This was later officially confirmed as the first such service in Australia. When road conditions were not good, however, Sutton and Gillespie reverted to use of the horsedrawn coaches on which Gillespie had made his reputation. As is quite clear from many accounts, the rudimentary state of the roads across the black soil plains made this a relatively common occurrence for many years after motor vehicles were introduced.

It was in these circumstances that corduroy was used to improve the road surface at water crossings and boggy areas beside creeks. Corduroy roads were once extremely common in many parts of Australia, very effective, and easily and quickly constructed. Using corduroy roads in the later stages of the American Civil War, General Sherman's troops advanced at a rate of $18 \mathrm{~km}$ per day through swamps, admirably demonstrating both the speed with which such roads could be built, as well as their efficacy (McPherson 1990:828). The corduroy sections reported here, therefore, almost certainly post-date 1891 . They probably represent the original alignment of the coach road south from Ilfracombe to Isisford until the road was designed and built on its current alignment sometime after World War II.

\section{Consequences of Pastoral Expansion in the Region}

The rapid expansion of Wellshot had some rather direct

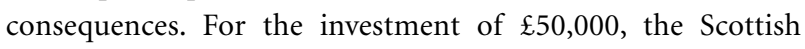

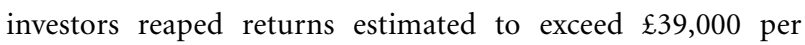
annum. The dividends during the salad years must have been grand even allowing for fluctuations in the wool price, which Svensen (1989:27-29) noted was reasonably static from 1886 through 1893. The value of QLD wool exports tripled from $\mathfrak{E} 1.3$ million in 1882 to greater than $\mathfrak{E} 4.2$ million in 1892 , and Wellshot would have taken a sizable portion of this. In 1888 and 1889 the net profit on the property, as a percentage of gross turnover, was 65\% and 61\%, respectively (Svensen 1989:29). It is little wonder that the property manager commanded a salary of $£ 850$ per annum if his stewardship was generating such cash streams (Forrest 1988:60). But the impacts went further than the simple cash return. Wellshot enjoyed a national reputation at this time and with wealth and prestige there comes celebrity and privilege. Thus, Cobb and Co ensured that only the best teams of horses were used on this run to impress important persons travelling to and from the station. Beyond these things, however, lay tremendous power. Wellshot and the other massive sheep 
and wool operations throughout this region had very large cash reserves due to the good years and massive expansion, and were integral to the well-being of the entire QLD economy.

In 1891, the station owners and their managers, with leadership from the Fairbairn family, decided to cut shearers' wages. They had little intention of ceding the wealth they were making, were fearful of union militancy and were looking to break the unions (Svensen 1989). The shearers' response to this assault on their living standards and working conditions resulted in the Great Shearers' Strike of 1891 (Svensen 1989).

Motivated, and with wealth, economic clout and political caché, the squatters had little hesitation in provoking the shearers. The colony's cavalry and infantry were put at the disposal of the squatters and used to protect properties from those striking shearers who were resorting to guerrilla tactics that included the sabotage of facilities and the burning of shearing sheds. The owners had already formed various representative organisations, and subscriptions were levied to establish a war chest to meet the many expenses of this quasi-military campaign?. Trains were chartered to carry the troops, as well as private security, food and accommodation secured to keep them in the field for the duration of the strike, and higher wages were paid to non-union strike breakers. Central western QLD was at the heart of the strike, and the shearers' strike camp at Lagoon Creek on the outskirts of Barcaldine and the Tree of Knowledge in the centre of the town are two of the best known sites associated with it (Egloff et al. 1991).

Flexing their muscle, the property owners won this fight, breaking the strike after four months, securing the right to employ non-union labour as they chose and seeing various union leaders serve lengthy jail sentences for their part in the strike. The profits that paid for this success were underwritten by innovative property developments such as the Shotover. Ironically, the year of the strike also saw the single largest shearing of sheep raised on one property in Australian history, when 425,000 sheep passed through the Wellshot sheds. Almost certainly this event involved some of the very shearers who had been on strike, seemingly brought to heel by impecunity and the aggressive response of the owners.

The psychological impacts and political consequences of this sequence of events, which ultimately led to the formation of the Australian Labor Party (ALP) ${ }^{10}$ were huge, even if there is not the line of direct historical causality some believe to be the case (Svensen 1989:256). Adversity provoked a response from the shearers and other unionists that was perhaps as unexpected as it was far-reaching. They decided to appropriate the power with which they had been confronted by seeking political influence themselves. Mobilising their numbers, they pursued election to both local and state governments, with considerable success in 1891 and after (Svensen 1989:214-216). Central western QLD

\footnotetext{
${ }^{9}$ The tone of the time is captured in Lawson's poem Freedom on the Wallaby:

We'll make the tyrants feel the sting

Of those that they would throttle,

They needn't say the fault is ours

If blood should stain the wattle.

${ }^{10}$ There is some debate as to exactly what role the Shearers' Strike of 1891 played in the formation of the ALP. There is no doubt, however, that it is at the emotional heart of the labour movement. Visits of ALP politicians and union leaders to Barcaldine on the centenary of the Strike, for other purposes linked to the history of the labour movement, and patronage of the Workers' Hall of Fame which now sits in Barcaldine, make this clear.
}

continued to elect numerous representatives from the ALP to both State and Commonwealth governments, until the late 1950s, contributing to the formation of Labor governments from 1899 onwards.

This unexpected outcome was also, in part at least, a result of a set of environmental circumstances of relatively short duration that would never be repeated. The environmental conditions in which innovative property management, such as the Shotover, proved so effective during the 1880s and early 1890 s, were an aberration. This decade was an unusually wet period in the greater region of central QLD. It saw the development of numerous sugar plantations on the coast near to, and in the immediate hinterland around, Rockhampton, which is a far drier area than the wet tropics regions of Mackay and Bundaberg, where the sugar industry first emerged and still exists today (McDonald 1995:63, 67-68). These plantations near Rockhampton flourished, employing large numbers of South Sea Islanders to clear scrub, pile rocks and create the fields that could be ploughed and planted. Refining mills and private roads built to get product to ships for the export market followed ${ }^{11}$. The return to drier conditions in the mid-1890s, reflecting those that are more usual in this region, saw plantations collapse as crops withered and profits just as quickly turned to losses. The short histories of the plantations at Farnborough and Alton Downs are examples of the rapid efflorescence, short-lived nature and equally quick demise of the sugar industry in this area. Facilities such as the Shotover delivered the property growth and profits that characterised this period in central western QLD in part only because of this aberrant wet period. The use of GAB groundwater, which overlapped with this, perhaps has hidden this fact in central western QLD. For other parts of the continent it did not. For instance, the pastoral industry based on sheep in the Lachlan River region of NSW, which had expanded at rates comparable with central western QLD and at much the same time, suffered wholesale catastrophic collapse when the drought of the mid-1890s took hold, although conditions were exacerbated by a rabbit plague, amongst other things (see Cannon 1992 for a detailed analysis of this phenomenon).

Noting that surface water management alone would not have allowed the property growth, stock numbers and stocking rates, except probably in these environmentally unusual circumstances, it is a matter of some interest whether use of the GAB would have made them possible in the first place, or could have sustained them in the long-term. It is true that flock numbers and stocking rates quickly returned to previous historically high levels after the Federation Drought. This suggests that a GAB-based management regime could have underwritten the expansion program. The timing of that expansion would, however, have been at least a decade later than it was, perhaps with interesting historical implications to ponder. Whether the massive drawdown on GAB groundwater that resulted was sustainable in the long-term is debatable. Table 5 shows figures of water flows from one set of springs in the GAB from the 1890s to the 1990s, a pattern well-documented across the GAB. The remarkable fact is that all of them show tremendously reduced flows only 100 years after the system was tapped and use made of its waters for stock management. This is not to suggest that the total amount

\footnotetext{
${ }^{11}$ The sugar trail constructed near Yeppoon, and now on the state heritage register, is one such example.
} 
of groundwater in the system has been reduced by this amount, but rather that flow rates to springs and bores have been greatly reduced. In these circumstances, and noting that stock numbers and stocking rates on properties have greatly diminished since the halcyon days of the 1880 s and hence decreased the need for water from the $G A B$, it is difficult to see that use of the GAB would have sustained those numbers in the long-term, even if government action to split up the huge holdings had not intervened to make a Wellshot of the 1880s an impossibility in any case.

\section{Conclusions}

Prior to the construction of facilities such as the Shotover, sheep numbers and stocking rates in central western QLD were directly linked to the availability of naturally-available surface water. No matter how much feed might be available, large areas had to be abandoned as soon as it became imperative to move flocks to another location where water could be found. This demand meant that numbers and rates were contingent on the amount of feed within easy walking access of water. The Shotover, and facilities like it, broke open this equation: they harnessed surface water and made it available for much longer periods after rain than would otherwise have been the case. Flocks could now be depastured for significantly longer periods of time in areas where feed remained abundant, but naturally-available surface water was scarce, and thus much larger areas of the property became useful for extended periods.

It was this capture and use of surface water that allowed the historically high rates of stocking to be achieved, an increase of near ten-fold on rates achieved before this using naturallyavailable water, and apparently with less risk. These measures did not, however, drought-proof these properties. Nor, of course, was this subsequently attainable using groundwater drawn from the GAB. The Federation Drought proved this. Bores, pipes, bore drains and turkey nests allowed water to be shifted to places on the property where feed was still abundant, and in that fashion served a similar purpose to facilities like the Shotover. The amounts of water from this source were also far more prolific and virtually permanent when compared with what could be captured using surface water management facilities alone. Even so, the drought had a catastrophic impact. It demonstrated that, if the drought were long enough, the feed needed to sustain the flock eventually would be exhausted even if water was still available in apparently limitless amounts, shifting the stocking equation back to one

Table 5 Flow data for GAB bores in the Eulo Spring supergroup area (after Fairfax and Fensham 2003).

\begin{tabular}{|c|c|c|c|}
\hline Bore Name & Pre-1913 Flow (L/day) & Recent Flow (L/day) & $\%$ Pre-1913 Flow \\
\hline 4560 & 285,120 & 144,288 & 50.6 \\
\hline Mulgar (9) 4553 & 998,011 & 340,416 & 34.1 \\
\hline 1491 & 31,104 & 8640 & 27.8 \\
\hline Kungie 4550 & $1,168,655$ & 304,992 & 26.1 \\
\hline 403 & $16,498,080$ & $4,192,128$ & 25.4 \\
\hline Tunka 167 & 13,608 & 3456 & 25.4 \\
\hline Taleroo 169 & 340,200 & 76,896 & 22.5 \\
\hline 1831 & 307,584 & 63,936 & 20.8 \\
\hline Wooregym 1488 & 217,728 & 43,200 & 19.8 \\
\hline Woolshed (2) 1616 & 90,720 & 17,280 & 19.0 \\
\hline 4547 & $2,445,984$ & 315,360 & 12.9 \\
\hline 2272 & $5,069,088$ & 595,296 & 11.7 \\
\hline 4551 & $12,274,848$ & $1,294,272$ & 10.5 \\
\hline 1821 & $5,908,896$ & 610,848 & 10.3 \\
\hline 4552 & $1,249,344$ & 67,392 & 5.4 \\
\hline 2276 & $6,590,592$ & 330,912 & 5.0 \\
\hline Colanya 1613 & 408,240 & 19,872 & 4.9 \\
\hline Bingara 1486 & 181,440 & 6912 & 3.9 \\
\hline 4561 & $5,227,200$ & 145,152 & 2.8 \\
\hline 402 & $11,643,264$ & 203,904 & 1.8 \\
\hline Tunca 1487 & 90,720 & 0 & 0 \\
\hline Tarko 1490 & 45,360 & 0 & 0 \\
\hline Woolshed 1614 & 77,112 & 0 & 0 \\
\hline Caiwarro 1820 & 113,400 & 0 & 0 \\
\hline 1822 & 12,960 & 0 & 0 \\
\hline 2275 & 432,000 & 0 & 0 \\
\hline Ooliman 2427 & 127,008 & 0 & 0 \\
\hline 2429 & 104,544 & 0 & 0 \\
\hline Mulgar (11) 4554 & $4,091,904$ & 0 & 0 \\
\hline Boortra 4556 & $12,273,120$ & 0 & 0 \\
\hline Tinnenburra (1) 4558 & $4,089,312$ & 0 & 0 \\
\hline Mulgar (10) 4559 & 136,080 & 0 & 0 \\
\hline Total & $92,543,226$ & $8,785,152$ & 9.5 \\
\hline
\end{tabular}


simply of the availability of adequate amounts of feed. Also notable is that GAB-based pastoral management did not allow stocking rates that exceeded those achieved earlier. The strategy to reduce risk and to stock at ever higher rates had hit its threshold: there always remained insoluble environmental constraints.

Those who designed and implemented improvements like those developed on Wellshot between 1880 and 1884 were innovative thinkers seeing the huge potential in front of them. They may have baulked at the cost of drilling down to the GAB and tapping its waters, but after a few years they took on this challenge and successfully applied the technology. But, as the Federation Drought amply demonstrated, they never managed to drought-proof their properties, despite the hubris of their claims. It is equally true that they cannot have imagined the political consequences of the decisions they made using the great wealth they had generated with their technical innovations. A curious chain of connection links something as prosaic as the Wellshot Shotover to events that continue to reverberate in the political institutions of the nation and sees questions of water management resonating at all levels of government to this day.

\section{References}

\section{BOM-see Bureau of Meterology}

Border, A. and M.J. Rowland 1990 The Mitchell Grass Downs Biogeographical Zone (Queensland): A Heritage Resource Assessment. Unpublished report prepared for the Heritage Branch Department of Environment and Heritage, Brisbane and Australian Heritage Commission, Canberra.

Bourne, G. 1863 Journal of Landsborough's Expedition from Carpentaria in Search of Burke and Wills. Melbourne: H.T. Dwight.

Bureau of Meteorology 2012 Climate data online. Retrieved 14 March 2012 from http://www.bom.gov.au/climate/data/

Cannon, A. 1992 Woolsheds and catastrophe theory: The Lower Lachlan experiment. Australian Journal of Historical Archaeology 10:65-74.

Connah, G. 1977 Wool, water and settlement: The archaeological landscape of Saumarez Station. Armidale and District Historical Society Journal 20:117-127.

Connah, G. 1988 Of the Hut I Builded: The Archaeology of Australia's History. Cambridge: Cambridge University Press.

Cummins, R.D. 1989 Scouring the clip: Boom and burn on woolscour lane. Australian Journal of Historical Archaeology 7:23-28.
Egloff, B.J., M. O'Sullivan and J. Ramsay 1991 Archaeology of the 1891 Shearers' War: The main strike camp at Barcaldine, Queensland. Australian Journal of Historical Archaeology 9:63-75.

Evans, R., K. Saunders and K. Cronin 1993 Race Relations in Colonial Queensland. St Lucia: University of Queensland Press.

Fairfax, R.J. and R.J. Fensham 2003 Spring wetlands of the Great Artesian Basin, Queensland, Australia. Wetlands Ecology and Management 11:343-362.

Forrest, P. 1988 A Rush for Grass. Darwin: Murranji Press.

Godwin, L. 1986 The Historical Landscape of the Uralla Shire. Unpublished report prepared for Myers Architects.

Hoch, I. 1990 Barcaldine 1846-1986. Barcaldine: Barcaldine Shire Council.

Huff, L., L. McDonald and D. Myers 1993 Sin, Sweat and Sorrow: The Making of Capricornia Queensland, 1840s-1940s. Rockhampton: University of Central Queensland Press.

Kennedy. E.B. 1852 Extracts from the Journal of an Exploring Expedition into Central Australia to Determine the Course of the River Barcoo. London: Royal Geographical Society.

Leichhardt, L. 1847. Journal of an Overland Expedition in Australia from Moreton Bay to Port Essington, A Distance of Upwards of 3000 Miles, During the Years 1844-45. London: T \& W Boone.

McDonald, L. 1995 Rockhampton: A History of City and District. Rockhampton: Rockhampton City Council.

McPherson, J.M. 1990 Battle Cry of Freedom: The American Civil War. London: Penguin Books.

Mitchell, T.L. 1848 Journal of an Expedition into the Interior of Tropical Australia in Search of a Route from Sydney to the Gulf of Carpentaria. London: Longman, Brown, Green and Longmans.

Pearson, M. 1984 The excavation of the Mount Wood wool scour, Tibooburra. Australian Journal of Historical Archaeology 2:38-50.

Phelps, D. 2007 Mitchell grass tips for drought recovery. In J. Milburn (ed.), Drought Survival Stories 3, pp.14-17. E-book, Leading Sheep.

Stanton, J.P. and G. Morgan 1977 The Rapid Selection and Appraisal of Key and Endangered Sites: The Queensland Case Study. Unpublished report prepared for the Department of Environment, Housing and Community Development.

Svensen, S. 1989 The Shearers' War: The Story of the 1891 Shearers'Strike. St Lucia: University of Queensland Press. 